\title{
MANAJEMEN WAKTU GEOLOG WANITA (GEOLOGIWATI), UNTUK MENJALANI PERAN SEBAGAI IBU RUMAH TANGGA DAN PEKERJA (STUDI KASUS DI KABUPATEN SLEMAN)
}

\author{
Winarti dan Rr. Amara Nugrahini \\ Program Studi Teknik Geologi STTNAS Yogyakarta \\ e-mail: winyayadida@yahoo.com
}

\begin{abstract}
ABSTRAK
Penelitian ini dilatar belakangi oleh peran ganda yang mampu dijalani oleh Geologiwati sebagai ibu rumah tangga dan pekerja, terutama di wilayah Kabupaten Sleman. Diantara Geologiwati tersebut bekerja di sektor pendidikan yaitu sebagai guru dan dosen serta bekerja di Dinas Sumber Daya Air dan Mineral Kabupaten Sleman, dengan jumlah 18 orang. Tujuan penelitian adalah mengetahui bagaimana manajemen waktu yang diterapkan para Geologiwati, sehingga mereka bisa mengembangkan diri dalam pekerjaan, tetapi juga sukses berperan sebagai ibu rumah tangga. Metode yang dipergunakan dalam penelitian ini adalah mengumpulkan data primer melalui angket. Berdasarkan tingkat pendidikannya, Geologiwati umumnya berpendidikan S-1 dan S-2 sebanyak 80\%, dan S-3 sebanyak 20\%. Dari sisi golongan, kebanyakan Geologiwati mempunyai golongan III dan ada yang mencapai IVd. Banyak diantara mereka yang memangku jabatan penting di beberapa Instansi seperti Pembantu Rektor, Ketua Jurusan, Kepala Pusat Studi dan Kepala Sub Bagian. Rata-rata waktu yang dipergunakan untuk berperan sebagai ibu rumah tangga sebanyak 13.83 jam, sedangkan 10.17 jam sisanya dipakai untuk bekerja. Bagi Geologiwati yang mempunyai jabatan umumnya mempunyai asisten di kantor, sedangkan dalam menjalani peran sebagai ibu rumah tangga umumnya mereka dibantu oleh orang lain (suami, orang tua, pembantu, anak). Selain itu dalam menjalani peran sebagai ibu, mereka mempunyai skala prioritas dalam menjalankan pekerjaan. Pekerjaan utama yaitu mengurus anak dan suami, dilakukan sendiri, sedangkan pekerjaan rumah lainnya dikerjakan oleh orang lain. Beberapa alasan Geologiwati tersebut menekuni bidang geologi karena profesi yang mulia, dapat berhubungan langsung dengan masyarakat, ada kesempatan untuk menjelajah daerah/negara lain, pola pikir, pengetahuan dan wacana baru selalu berkembang, masih sedikitnya wanita yang bekerja di geologi, kesempatan berkarier masih terbuka dan bisa menjadi wanita mandiri.
\end{abstract}

Kata kunci : Geologiwati, Peran Ganda, manajemen

\begin{abstract}
The study on the back by the multiple roles that is able to be lived by Geologiwati as housewives and workers, especially in the district Sleman Geologiwati. Among those working in the education sector is as a teacher and lecturer, and worked at the Department of Water and Mineral Resources Sleman regency, with the overall otal there are 18 people. The purpose of this study was to determine how time management is actually implemented by the Geologiwati, so that they can still develop themselves in the work, but also a successful role as a housewife. The method used in this research is to collect primary data through questionnaires. Based on the level of education, general education Geologiwati $S-1$ and S-2 by $80 \%$, and S-3 as much as 20\%. In terms of class, most class III and Geologiwati has anyone reached IVD. Many of those who hold important positions in several institutions such as the Vice Chancellor, Head of Department, Head of the Centre for Studies and Head of Section. The average time used to act as a housewife as 13.83 hours and 10.17 hours while the rest is used for work. For those who have positions Geologiwati generally have an assistant in the office, while in the lead role as a housewife generally they are assisted by others (husband, parents, helpers, and children). Besides the lead role as a mother, they have the highest priority in running job. The main job is to take care of children and husbands, done alone, while the other house work done by others. Some of the reasons Geologiwati pursue the field of geology as a noble profession, can diel directly with the public, there is a chance to roam the area / country, mindset, knowledge and platform is always evolving, still at least a woman who worked in geology, career opportunity is still open and mand can be a woman.
\end{abstract}

Keywords : Geologiwati, Multiple Roles, Management 


\section{PENDAHULUAN}

Pada zaman sekarang ini kaum wanita dapat bekerja di segala bidang, seperti bidang pendidikan, perbankkan, kepolisian, pemerintahan, bahkan di bidang eksplorasi geologi atau pertambangan. Hal ini dibuktikan dengan semakin banyaknya jumlah mahasiswi yang mengambil jurusan Geologi atau pertambangan. Disisi lain, seorang wanita juga berfungsi sebagai ibu rumah tangga dengan tugas mengurus semua pekerjaan rumah. Pekerjaan rutin ini membutuhkan waktu yang tidak sedikit dan cukup banyak menguras energi.

Wanita yang dapat menjalani peran ganda sebagai ibu rumah tangga dan karyawati, tentunya memiliki manajemen yang baik. Hal tersebut disebabkan karena mereka harus pandai-pandai membagi waktu, tenaga, pemikiran untuk di rumah dan kantor. Salah satu sektor pekerjaan yang mempunyai tantangan cukup berat untuk dikerjakan oleh kaum wanita adalah menjadi Geologiwati, seperti bekerja di bidang eksplorasi, jasa/konsultan, pengajar dan di beberapa perusahaan. Hal ini disebabkan karena diperlukan kekuatan/ketahanan fisik dan waktu yang cukup lama. Terutama apabila suatu saat mereka harus melakukan survei lapangan. Pada kenyataannya sebagian dari wanita mampu menekuni bidang Geologi atau pertambangan tersebut cukup lama, bahkan ada diantara mereka yang menjadi pucuk pimpinan di suatu lembaga/instansi.

Maksud dari penelitian ini adalah memperoleh data sebaran dari Geologiwati yang bekerja di beberapa sektor pekerjaan di lingkup wilayah Kabupaten Sleman. Sedangkan tujuannya adalah mengetahui bagaimana Geologiwati membuat sistem manajemen waktu, sehingga mereka tetap bisa mengembangkan diri dalam pekerjaan, sukses berperan sebagai ibu rumah tangga. Selain itu apa yang melatarbelakangi mereka untuk tetap menekuni bidang Geologi sampai saat ini.

\section{Geologi dan Geologiwati}

\section{TINJAUAN PUSTAKA}

Geologi merupakan ilmu yang mempelajari tentang bumi (earthly science). Isitilah ini pertama kali diperkenalkan oleh Richard de Bury pada tahun 1473. Sedangkan orang yang memperkenalkan geologi modern adalah James Hutton pada tahun 1795 [1]. Orang yang mempelajari geologi disebut ahli geologi atau geologist (geologiawan atau geologiwati). Sedangkan Geologiwati yang menjadi subjek dalam penelitian ini adalah wanita-wanita yang sudah berhasil menyandang predikat sarjana di bidang geologi dan menjalani profesi di bidang geologi.

Geologi mempelajari bumi secara menyeluruh, seperti proses pembentukan bumi dari dalam, bagian-bagian dan komposisi bumi, sejarah pembentukan dan juga prosesproses alam yang telah dan sedang berlangsung hingga saat ini, sehingga dapat menghasilkan kenampakan seperti saat ini. Cabang-cabang ilmu geologi diantaranya : Mineralogi, Petrologi, Stratigrafi, Paleontologi, Geologi Struktur, Geomorfologi, Geofisika, Geokimia, dan lain sebagainya. Dalam aplikasinya geologi banyak dipakai dalam bidang eksplorasi (bahan tambang, air tanah ataupun minyak dan bumi), Geotek, Volkanologi, tata lingkungan dan lain sebagainya. Semua bidang-bidang tersebut mengharuskan seorang geolog untuk melakukan kunjungan lapangan. Hal ini tentunya selain memerlukan penguasaan materi, stamina fisik yang baik dan alokasi waktu yang lama. Sehingga sering kali pekerjaan lapangan geologi selalu diidentikkan dengan kaum pria. Akan tetapi seorang Geologiwati dikisahkan mampu berpetualang di lapangan untuk melakukan pemetaan baik di Jawa atau di luar Jawa dengan medan dan tantangan alam yang cukup berat sekaligus yang bersangkutan mampu menjadi istri dan ibu rumah tangga yang sukes [2]. 


\section{Manajemen}

Secara umum manajemen diartikan sebagai suatu metode/teknik atau proses untuk mencapai suatu tujuan tertentu secara sistematik dan efektif, melalui tindakan-tindakan perencanaan (Planning), pengorganisasian (Organizing), pelaksanaan (Actuating) dan pengawasan (Controlling) dengan menggunakan sumber daya yang ada secara efisien. Soeharto mendefinisikan manajemen adalah proses merencanakan, mengorganisir, memimpin dan mengendalikan kegiatan anggota serta sumber daya yang lain untuk mencapai sasaran organisasi (perusahaan) yang telah ditentukan [3]. Sedangkan yang dimaksud dengan proses adalah mengerjakan sesuatu dengan pendekatan tenaga, keahlian, peralatan, dana dan informasi. Hampir semua segi kehidupan memerlukan adanya manajemen, supaya masing-masing kegiatan dapat dilaksanakan sesuai dengan tujuan

Salah satu manajemen yang dianggap penting adalah manajemen waktu (time management). Hal ini disebabkan karena waktu tidak bisa diulang kembali atau dilambatkan. Waktu adalah hidup dan modal kita. Definisi dari manajemen waktu adalah usaha manusia mengatur dan mengelola masa hidupnya di dunia yang diberikan oleh Tuhan agar hidupnya tersebut mendapatkan bermanfaat di dunia dan akherat. Manajemen waktu termasuk ke dalam proses yang akan diperlukan untuk memastikan waktu penyelesaian suatu pekerjaan. Sistem manajemen waktu berpusat pada berjalan atau tidaknya perencanaan dan penjadwalan suatu kegiatan [4].

Dalam keseharian waktu yang tersedia selalu tetap yaitu selama 24 jam. Tentunya waktu tersebut amat terbatas, mengingat tugas yang harus dikerjakan cukup banyak, baik di dalam ataupun di luar rumah. Sehingga kadang-kadang waktu 24 jam tersebut tidak cukup. Apalagi seorang ibu rumah tangga yang bekerja, karena selain mengurus semua urusan rumah tangga juga bertanggungjawab terhadap perekerjaan kantor. Manajemen waktu adalah strategi penting yang perlu diterapkan oleh para ibu bekerja untuk dapat mengoptimalkan perannya sebagai ibu rumah tangga, istri dan sekaligus karyawati [5]. Inti dari manajemen waktu adalah konsentrasi pada hasil dan bukan sekedar menyibukkan diri. Banyak orang menghabiskan hari-harinya dengan berbagai kegiatan yang seakan tiada habisnya tetapi tidak mendapat capaian apapun karena kurang konsentrasi pada hal yang benar.

Dalam menjalankan memanajen waktu maka pertama kali manuasia harus memiliki komitmen untuk mengatur waktu. Langkah selanjutnya adalah merencanakan dan memprioritaskan waktu dengan menuliskan tujuan hidup. Manajemen waktu secara tertulis tidak hanya membuat sesuatu yang direncanakan mejadi lebih efektif, namun juga memperdalam komitmen hadap suatu tujuan. Idialnya sistem perencanaan waktu mengikat elemen-elemen, seperti merencanakan aktivitas (harian, mingguan, bulanan, tahunan) dan semuannya harus terdaftar (tertulis), menetapkan tujuan dari semua rencana aktivitas tersebut serta menyusun daftar kerja sesuai skala prioritas.

Sebuah sistem manajemen waktu yang sesuai dengan kebutuhan, tentunya dapat membantu dalam menyelesaikan pekerjaan dalam waktu singkat yaitu dengan membuat skala prioritas dari banyak kegiatan yang direncanakan. Dengan demikian maka dalam melalukan aktivitas terhindar adanya tabrakan waktu, membantu menghindari perasaan bersalah, tercipta hidup yang seimbang dan selaras, dapat merencanakan tujuan dengan baik serta akan lebih produktif.

\section{METODE PENELITIAN}

Dalam melakukan penelitian ini dilakukan beberapa metode, diantaranya:

1. Riset perpustakaan yaitu mencari, membaca, serta memahami berbagai buku/pustaka yang erat kaitannya dengan masalah yang dibahas. 
2. Riset lapangan yaitu meninjau secara langsung ke lapangan untuk mencari informasi ke beberapa instansi untuk mendapatkan data sebaran Sarjana Geologi.

3. Riset website internet yaitu pengumpulan data melalui penjelajahan berbagai website internet dengan situs yang sesuai dengan permasalahan.

4. Riset pengangketan yaitu pengumpulan data dengan penyebaran angket dengan pertanyaan sesuai dengan permasalahan.

Untuk memudahkan dalam melakukan penelitian dan penelitian ini nantinya bisa sistematis, maka dibuat tahapan penelitian yang meliputi:

1. Tahap studi pustaka. Pada tahap ini dilakukan untuk mencari sumber referensi seperti buku, jurnal ilmiah dan brosing internet yang sesuai dengan topik permasalahan.

2. Tahap mencari data ke Intansi/Perguruan Tinggi yang ada di Wilayah Kabupaten Sleman. Instansi yang dimaksud meliputi beberapa Perguruan Tinggi (UGM, UPN Veteran dan STTNAS), serta Badan Kepegawaian Daerah Kabupaten Sleman.

3. Tahap penyusunan angket yang berisikan beberapa pernyataan/permasalahan yang memerlukan opini atau tanggapan dari geolog wanita (Geologiwati). Jumlah pernyataan sebanyak 20, yang terdiri dari 10 pernyataan pilihan dan 10 isian.

4. Tahap sosialisasi dan penyebaran angket dengan tujuan untuk mendapatkan umpan balik dari konsumen (Geologiwati) dan menginventaris data tersebut untuk selanjutnya dilakukan analisis. Sosialisasi dan penyebaran angket dilakukan ke beberapa instansi, dengan jumlah responden sebanyak 18 orang.

5. Tahap evaluasi yang dilakukan untuk mengevaluasi hasil angket yang dianalisis dengan menggunakan statistik kualitatif. Dalam analisis statistik berdasarkan tingkat pengukurannya (level of measurement) dapat dibedakan dalam 2 jenis:

a. Analisis kuantitatif adalah analisis yang berbasis pada kerja hitung-menghitung angka. Angka yang diolah disebut input dan hasilnya disebut output juga berupa angka. Analisis ini berbasis pada kerja pengelompokan simbol-simbol selain angka. Simbol itu berupa kata, frase, atau kalimat yang menunjukkan beberapa kategori. Input maupun output analisis datakualitatif berupa simbol, dimana outputnya disebut deskripsi verbal.

b. Analisis kualitatif yang secara sederhana bisa disebut analisis data yang bukan berupa angka. Analisis kualitatif tidak menekankan pada kajian deskripsi sekilas dengan jumlah sampel yang besarnya/banyaknya tidak seperti pada metode kuantitatif. Pada penelitian ini tidak ada perlakuan atau manipulasi variable. Perbedaan mendasar dari metode penelitian kualitatif dibandingkan dengan penelitian kuantitatif adalah dari pembuktiannya yang bersifat induktif. Metode penelitian kualitatif sering digunakan untuk meneliti hal-hal yang sulit terungkap dengan penelitian kuantitatif seperti nilai yang dianut masyarakat, motivasi terdalam yang membuat responden memilih pilihan tertentu atau alasan-alasan. Karena tujuan utama dari metode penelitian kualitatif adalah mendapatkan pemahaman melalui pengalaman, maka peneliti sering berinteraksi langsung dengan subjek penelitian. Kemampuan peneliti dalam mengumpulkan data, menggali informasi dan menginterpretasikan hasil, menjadi penentu dalam penelitian kualitatif. Dalam menyusun pertanyaan biasanya lebih terbuka dengan kata 'mengapa' dan 'bagaimana'.

\section{HASIL DAN PEMBAHASAN}

Berdasarkan hasil pelacakan data responden, maka diperoleh sebaran Geologiwati yang bekerja di wilayah Kabupaten Sleman sebanyak 18 orang, dengan rincian sebagai berikut (Tabel 1): 
1. Jumlah keseluruhan Pegawai Negeri yang bekerja di lingkungan Pemerintah Kabupaten (Pemkab) Sleman ada 5 orang Sarjana Geologi Wanita (Geologiwati).

2. Data dari Perguruan Tinggi meliputi UGM, UPN "Veteran" dan STTNAS, Yogyakarta menunjukkan bahwa Sarjana Geologi Wanita (Geologiwati) yang bekerja sebagai dosen di Jurusan Teknik Geologi UPN "Veteran" Yogyakarta sebanyak 4 orang, di Jurusan Teknik Geologi Universitas Gadjah Mada Yogyakarta sebanyak 4 orang dan di Program Studi Teknik Geologi, Sekolah Tinggi Teknologi Nasional Yogyakarta, ada 4 orang sebagai dosen dan 1 orang sebagai laboran.

Sehingga berdasarkan data tersebut, jumlah Sarjana Geologi Wanita (Geologiwati) yang bekerja di lingkungan Pemerintah Kabupaten Sleman dan beberapa Perguruan Tinggi yang ada di Kabupaten Sleman, yang dapat terpetakan sebanyak 18 orang. Jumlah tersebut nantinya akan ditindaklanjuti untuk dijadikan responden pengisian angket (kuisioner).

Tabel 1. Daftar Sebaran Sarjana Geologi Wanita (Geologiwati) yang Bekerja di Beberapa Instansi yang Ada di Wilayah Kabupaten Sleman

\begin{tabular}{|c|c|c|c|}
\hline NO & NAMA & PENDIDIKAN & UNIT KERJA \\
\hline 1 & Ir. Endang Purwantiningsih & S-1/Teknik Geologi & $\begin{array}{l}\text { Dinas Sumber Daya Air, Energi, dan Mineral, } \\
\text { Pemkab Sleman }\end{array}$ \\
\hline 2 & $\begin{array}{l}\text { Evi Novitasari } \\
\text { Prasetyaningrum, ST }\end{array}$ & S-1/Teknik Geologi & $\begin{array}{l}\text { Dinas Sumber Daya Air, Energi, dan Mineral, } \\
\text { Pemkab Sleman }\end{array}$ \\
\hline 3 & Harti Widiyaningsih, ST & S-1/Teknik Geologi & $\begin{array}{l}\text { Dinas Sumber Daya Air, Energi, dan Mineral, } \\
\text { Pemkab Sleman }\end{array}$ \\
\hline 4 & Sri Purwanti Rahayu, ST & S-1/Teknik Geologi & SMA dan SMK Kecamatan Depok \\
\hline 5 & Himawati Widyastuti, ST & S-1/Teknik Geologi & SMA dan SMK Kecamatan Depok \\
\hline 6 & $\begin{array}{l}\text { Prof. Dr. Ir. Sari Bahagiarti } \\
\text { Kusumayudha, M.Sc }\end{array}$ & S-3/Teknik Geologi & $\begin{array}{l}\text { Dosen di Fakultas Teknologi Mineral UPN } \\
\text { "Veteran" Yogyakarta }\end{array}$ \\
\hline 7 & Dr. Ir. Premonowati, M.T. & S-3/Teknik Geologi & $\begin{array}{l}\text { Dosen di Fakultas Teknologi Mineral UPN } \\
\text { "Veteran" Yogyakarta }\end{array}$ \\
\hline 8 & $\begin{array}{l}\text { Ir. Siti Umiyatun Choiriah, } \\
\text { M.T. }\end{array}$ & S-2/Teknik Geologi & $\begin{array}{l}\text { Dosen di Fakultas Teknologi Mineral UPN } \\
\text { "Veteran" Yogyakarta }\end{array}$ \\
\hline 9 & $\begin{array}{l}\text { Intan Paramita Haty. S.T., } \\
\text { M.T }\end{array}$ & S-2/Teknik Geologi & $\begin{array}{l}\text { Dosen di Fakultas Teknologi Mineral UPN } \\
\text { "Veteran" Yogyakarta }\end{array}$ \\
\hline 10 & $\begin{array}{l}\text { Prof. Ir. Dwikorita } \\
\text { Karnawati, M.Sc., Ph.D. }\end{array}$ & S-3/Teknik Geologi & $\begin{array}{l}\text { Dosen di Jurusan Teknik Geologi UGM } \\
\text { Yogyakarta }\end{array}$ \\
\hline 11 & Ir. Pri Utami, M.Sc, PhD & S-3/Teknik Geologi & $\begin{array}{l}\text { Dosen di Jurusan Teknik Geologi UGM } \\
\text { Yogyakarta }\end{array}$ \\
\hline 12 & Ir. Dewi Titisari, MT. & S-2/Teknik Geologi & $\begin{array}{l}\text { Dosen di Jurusan Teknik Geologi UGM } \\
\text { Yogyakarta }\end{array}$ \\
\hline 13 & $\begin{array}{l}\text { Gayatri Indah Marliyani, } \\
\text { ST.,_M.Sc. }\end{array}$ & S-2/Teknik Geologi & $\begin{array}{l}\text { Dosen di Jurusan Teknik Geologi UGM } \\
\text { Yogyakarta }\end{array}$ \\
\hline 14 & Ir. Amara Nugrahini, MT & S-2/Teknik Geologi & $\begin{array}{l}\text { Dosen di Jurusan Teknik Geologi STTNAS } \\
\text { Yogyakarta }\end{array}$ \\
\hline 15 & $\begin{array}{l}\text { Th. Listyani Retno Astuti, } \\
\text { ST, MT }\end{array}$ & S-2/Teknik Geologi & $\begin{array}{l}\text { Dosen di Jurusan Teknik Geologi STTNAS } \\
\text { Yogyakarta }\end{array}$ \\
\hline 16 & Winarti, ST, MT & S-2/Teknik Geologi & $\begin{array}{l}\text { Dosen di Jurusan Teknik Geologi STTNAS } \\
\text { Yogyakarta }\end{array}$ \\
\hline 17 & $\begin{array}{l}\text { Bernadeta Subandini, } \\
\text { ST.,M.Eng }\end{array}$ & S-2/Teknik Geologi & $\begin{array}{l}\text { Dosen di Jurusan Teknik Geologi STTNAS } \\
\text { Yogyakarta }\end{array}$ \\
\hline 18 & $\begin{array}{l}\text { Margaretha Listiyowati, } \\
\text { ST. }\end{array}$ & S-1/Teknik Geologi & $\begin{array}{l}\text { Laboran di Jurusan Teknik Geologi STTNAS } \\
\text { Yogyakarta }\end{array}$ \\
\hline
\end{tabular}

\section{Tingkat Pendidikan dan Karier}

Berdasarkan hasil angket dengan jumlah responden sebanyak 18 orang Geologiwati, diperoleh $83,3 \%$ angket tersebut terisi dan dikembalikan, sedangkan sisanya 
$(16,7 \%)$ tidak kembali. Dari hasil pengisian angket tersebut diperoleh data sebagai berikut: geolog wanita (Geologiwati) yang bekerja di beberapa instansi rata-rata masih dalam usia sangat produktif, yaitu dikisaran umur antara 30-50 tahun. Sedangan masa kerja meraka di bidang geologi berkisar antara $<10$ tahun sampai 30 tahun.

Dilihat dari sisi golongan atau kepangkatan, kebanyakan Geologiwati tersebut mempunyai golongan III dan ada beberapa diantarannya yang sudah mencapai IV.d. Hal ini tentunya bukan sesuatu yang mudah untuk dicapai. Dibutuhkan kerja keras, loyalitas tinggi dan juga tingkat pendidikan yang tinggi pula pada bidang yang ditekuni. Berdasarkan hasil angket diketahui bahwa para Geologiwati tersebut mempunyai tingkat pendidikan mulai S-1, S-2 dan S-3. Dari tingkat pendidikan tersebut diketahui bahwa umumnya tingkat pendidikan mereka S-1 dan S-2 yaitu $80 \%$, sedangkan $20 \%$ nya mampu mencapai pendidikan sampai S-3.

Sebagai bukti lain dari eksistensi mereka dalam dunia kerja, banyak diantara mereka yang dipercaya memangku jabatan penting seperti Pembantu Rektor, Ketua Jurusan, Kepala Pusat Studi dan Kepala Sub Bagian. Dengan semakin tingginya jabatan yang diemban, maka semakin bertambah beban kerja, waktu dan pemikiran yang lebih banyak.

\section{Pembagian Waktu Dalam Menjalani Peran Ganda}

Ruang lingkup pekerjaan yang ditekuni oleh para Geologiwati umumnya tidak berbeda jauh dengan bidang geologi, diantarannya sebagai pendidik (dosen dan guru) di bidang geologi dan bekerja di Dinas (Pemkab) yang juga bergerak di bidang geologi (sumber daya air). Berdasarkan angket yang telah terisi diketahui bahwa 93,3\% Geologiwati adalah seorang ibu rumah tangga. Artinya bahwa mereka menjalankan peran sebagai ibu dari anak-anak dan juga sebagai istri. Dalam menjalankan fungsi sebagai ibu rumah tangga (ibu dan istri), para Geologiwati menjalankan peran seperti ibu rumah tangga pada umumnya seperti mengurus rumah, mengurus anak, berkebun, memasak dan lain sebagainya. Dalam menjalankan peran sebagai ibu rumah tangga, umumnya meraka lakukan sebelum berangkat ke kantor, atau sesudah pulang dari kantor dan juga pada saat libur.

Berdasarkan hasil angket juga diketahui bahwa rata-rata lamanya waktu berada di rumah dalam satu minggu adalah antara 90-120 jam, dengan jumlah hari kerja antara 5-6 hari dan jam kerja per harinya rata-rata 8 jam. Sehingga dalam satu minggu membutuhkan waktu untuk bekerja di kantor minimal antara 40 sampai 48 jam. Perhitungan jam tersebut belum termasuk jam lembur atau pekerjaan kantor yang dibawa pulang (diselesaikan di rumah). Hal ini perlu diperhitungkan mengingat 90\% responden menyatakan bahwa mereka terkadang membawa pekerjaan kantor untuk diselesaikan di rumah. Kondisi tersebut tentunya akan mengurangi lamanya jam mereka untuk berada di rumah, sehingga peran sebagai ibu dan istri di rumah akan berkurang.

Apabila dalam 1 minggu diambil rata-rata mereka mengerjakan pekerjaan kantor untuk dikerjakan di rumah (lembur) selama 14 jam (1 hari rata-rata 2 jam), maka tentunya hal itu akan menambah jumlah jam kerja. Sehingga waktu untuk dirumah yang semula 90120 jam, akan berkurang 14 jam, sehingga tinggal 76-106 jam. Dampanya apabila semula (sebelum ada jam lembur) jumlah jam untuk berada di rumah sekitar 16 jam, maka dengan adanya lembur maka sekarang tinggal 14 jam untuk dirumah.

Satu hal yang tidak bisa dianggap remah adalah dalam menjalani peran sebagai pekerja para Geologiwati tersebut terkadang harus ditugaskan ke luar kota atau kantor yang mengharuskan meraka tidak pulang atau harus menginap untuk beberapa hari. Kegiatan semacam ini tentunya juga banyak dilakukan oleh wanita-wanita yang bekerja pada bidang 
lainnya (pertanian, ekonomi, dan sebagainya). Sedangkan kepentingan mereka melakukan tugas luar tersebut dengan beberapa alasan diantarannya tugas penelitian lapangan, pembicara atau peserta dalam seminar baik di dalam atau di luar negeri, melakukan promosi, mendampingi mahasiswa, eksplorasi dan juga sebagai dosen tamu. Ada sedikit hal yang membedakan antara tugas luar seorang geolog dengan bidang yang lain. Sebagai contoh tugas melakukan pendampingan mahasiswa ke lapangan atau melakukan penelitian lapangan. Ketiga dihadapkan pada tugas tersebut, maka bukan hanya waktu dan pikiran yang harus disediakan dalam jumlah lebih. Akan tetapi juga memerlukan tenaga dan stamina fisik yang juga harus prima. Mengingat lapangan yang dimaksud adalah alam terbuka. Hal inilah yang membedakan antara pekerjaan seorang geolog wanita dengan pekerjaan wanita di bidang lainnya. Artinya bahwa selain pintar melakukan manajemen waktu, maka perlu juga ada manajemen kesehatan atau menjaga stamina

Berdasarkan hasil angket, dalam kurun waktu 1-3 bulan rata-rata para geolog wanita ditugaskan antara 1 sampai 3 kali. Sedangkan jangka waktu yang dibutuhkan untuk sekali penugasan antara 4-10 hari (beberapa diantaranya ada yang sampai >10 hari). Apabila diambil rata-rata, masa penugasan 7 hari (168 jam), dalam waktu 2 bulan (1440 jam), maka dalam satu hari waktu yang dipergunakan untuk mengerjakan pekerajaan di luar kantor bertambah 0.17 jam. Sehingga total waktu untuk bekerja 10.17 jam $(10+0.17)$ dan sisa waktu untuk berada di rumah tinggal 13.83 jam. Apabila dilogikakan, maka sisa waktu tersebut tidak mungkin seorang ibu bisa mengerjakan semua pekerjaan di rumah, belum lagi terpotong untuk istirahat.

Dampak dari hal tersebut, maka tidak semua pekerjaan rumah tersebut mampu meraka kerjakan atau selesaikan sendiri. Mengingat memang pekerjaan rumah merupakan pekerjaan yang tidak ada habisnya. Selain itu juga disebabkan karena terbatasnya waktu untuk berada di rumah. Untuk mengantisipasi tidak dapat terselesaikannya pekerjaan rumah tersebut, maka para Geologiwati memerlukan bantuan orang lain yang turut aktif membantu terutama menyangkut pekerjaan di rumah. Hal ini terbukti bahwa dari angket diketahui bahwa dalam menjalankan pekerjaan rumah sehari-hari, para Geologiwati dibantu oleh orang lain. Orang lain yang dimaksud bisa suami, anak, orang tua atau pembantu rumah tangga. Dalam hal pembagian kerja, pada umumnya geolog wanita lebih memilih mengerjakan pekerjaan rumah yaitu memasak, berkebun, mengurus anak/suami dan mengerjakan pekerjaan rumah yang sifatnya ringan. Sedangkan untuk pekerjaan rumah berupa membereskan rumah, mencuci, menyetrika, antar jemput anak sekolah (bagi yang anaknya masih perlu diantar) dan pekerjaan rumah yang bersifat berat, kebanyakan dikerjakan oleh orang lain (suami, pembantu, sopir). Walaupun ada juga (dari data angket), yang menyebutkan bahwa ada geolog wanita yang terjun langsung menyelesaikan semua pekerjaan, akan tetapi pada akhirnya ketika mereka harus tugas ke luar kota, semua pekerjaan tersebut di kerjakan oleh orang lain.

Berdasarkan pada kajian di atas, maka dapat disimpulkan bahwa dengan durasi waktu di rumah kira-kira 13.83 jam (termasuk waktu istirahat malam) dalam sehari ternyata tidak cukup untuk dapat menyelesaikan semua tugas-tugas di rumah. Untuk mengatasi supaya terjadi keseimbangan antara peran ibu dengan seorang pekerja, maka diperlukan adanya skala prioritas. Artinya seseorang harus bisa membuat skala prioritas, pekerjaan mana yang harus didahulukan dan dianggap penting (mempunyai bobot terbesar). Dari hasil kajian, maka dari beberapa pekerjaan rumah yang ditawarkan, maka skala prioritas yang menduduki peringkat paling penting adalah mengurus anak (sekolah, les dan segala yang berhubungan dengan anak). Sedangkan masalah makan dan pekerjaan rumah lainnya menyesuaiakan. Artinya apabila tidak bisa dikerjakan saat itu, maka bisa ditunda penyelesaiannya. 
Sedangkan untuk urusan pekerjaan di kantor, khususnya bagi mereka yang mempunyai jabatan maka memang dibantu oleh asisten. Sehingga peran asisten ini tentunya juga penting misalnya melakukan pengarsipan data, mengatur jadwal rapat/kuliah, dsb.

\section{Latar Belakang Menekuni Bidang Geologi dan Peran Lingkungan (Keluarga dan Tempat Kerja).}

Dapat menekuni suatu pekerjaan dengan masa kerja 10-30 tahun tentunya bukan sesuatu yang gampang. Tentunya ada alasan kuat atau hal yang melatarbelakanginya. Hasil angket menyebutkan bahwa ada beberapa alasan kenapa geolog wanita tersebut menekuni bidang geologi, diantarannya ada yang menyatakan sebagai salah sutu profesi yang mulia mengingat kaitan geologi dengan eksplorasi sumber daya alam dan bencana alam (longsor, gunung meletus, banjir, dsb). Sehingga dengan ilmu geologi, maka bisa memberikan kontribusi berupa mitigasi bencana. Di sisi lain dengan maraknya upaya eksplorasi, maka dituntut peran geologi dalam memperbaiki lingkungan. Mengingat geologi berakitan dengan alam, maka ada sebagain responden yang menyatakan ketertarikan dengan geologi karena berbuhungan dengan kehidupan masyarakat sehingga bisa berperan langsung dalam membangun bangsa. Selain itu ada kesempatan untuk menjelah daerah/negara lain dengan berbagai macam budaya dan latar belakang yang beragam. Hal ini mempengaruhi dalam pola pikir, pengetahuan dan wacana baru.

Dunia geologi yang identik dengan dunia lapangan mengakibatkan identik juga pekerjaan di geologi dengan kaum laki-laki. Hal ini juga yang melatarbelakangi sebagian geolog wanita untuk tetap eksis di geologi, yaitu masih sedikitnya wanita yang bekerja di geologi. Sebagian melihat bahwa dengan masih sedikitnya jumlah tersebutnya, maka kesempatan berkarier masih terbuka. Mengingat mempelajari alam merupakan bahan/materi yang tidak pernah ada habisnya, sehingga peluang menggali, meneliti dan mempelajari alam tidak akan pernah kehabisan vahan atau topik. Dengan tetap eksis di bidang geologi, maka diharapkan geolog wanita tersebut akan menjadi wanita-wanita yang mandiri dengan tetap mendapat dukungan keluarga.

Berdasarkan pada hasil angket yang menyebutkan bahwa masa kerja dari para geolog wanita yang pada umumnya sudah cukup lama ( $<10$ tahun sampai 30 tahun), maka dapat dikatakan bahwa mereka sangat menikmati dengan kondisi pekerjaan tersebut. Tentunya dengan segala konsekuensinya baik suka maupun duka.Untuk bisa menikmati lingkungan kerja, segala aktivitas dan tanggungjawab pekerjaan selama itu tentunya tidak mudah. Selain adanya loyalitas (faktor internal dari diri sendiri) juga tidak terlepas dari dukungan lingkungan (faktor eksternal). Lingkungan yang dimaksud bisa lingkungan keluarga ataupun kantor (tempat kerja).

Pada umumnya (hasil angket) diketahui bahwa 100\% faktor lingkungan sangat mendukung kinerja dari para geolog wanita tersebut dalam menjalankan pekerjaan. Hal tersebut tercermin dari dukungan keluarga (suami, orang tua, anak) dalam bentuk turut membantu menyelesaikan pekerjaan rumah, ataupun dukungan pimpinan di kantor yang diwujudkan dalam memberi kesempatan, memberikan ijin keluar dan lain sebagainya.

\section{KESIMPULAN}

Berdasarkan hasil kajian dan ulasan, maka diketahui bahwa berdasarkan tingkat pendidikan geolog wanita yang berpendidikan S-1 dan S-2 sebanyak 80\% dan S-3 sebanyak 20\%. Dari sisi golongan atau kepangkatan geolog wanita mempunyai golongan III dan ada beberapa mencapai IV.d. Banyak diantara mereka yang memangku jabatan penting seperti Pembantu Rektor, Ketua Jurusan, Kepala Pusat Studi dan Kepala Sub 
Bagian. Rata-rata dalam satu hari waktu untuk berada di rumah berperan sebagai ibu rumah tangga 13.83 jam, sedangkan 10.17 jam sisanya untuk bekerja di luar rumah. Dalam menjalani peran sebagai ibu rumah tangga para geolog wanita umumnya dibantu oleh orang lain (suami, orang tua, pembantu, anak) dan mereka mempunyai skala prioritas pekerjaan. Pekerjaan mengurus anak sekolah, les dan suami menjadi skala prioritas dan pekerjakan rumah lainnya dipercayakan kepada orang lain. Alasan para geolog wanita menekuni bidang geologi katrena dianggap salah sutu profesi yang mulia, banyak berbuhungan dengan kehidupan masyarakat, ada kesempatan untuk menjelajahh daerah/negara lain, pola pikir, pengetahuan dan wacana baru selalu berkembang, masih sedikitnya wanita yang bekerja di geologi, kesempatan berkarier masih terbuka dan bisa menjadi wanita mandiri.

\section{DAFTAR PUSTAKA}

[1].Rogers, J.J.W., \& Adams J.A.S., 1966, Fundamentals Of Geology, New York and London, Harpre \& Row.

[2].Kartomihardjo, R.S., Suwarna N., dan Bachtiar, T., 2011, Suka Duka Penjelajah Geologi Di Indonesia, Kisah Para Pemeta Geologi, Bandung, Badan Geologi

[3].Soeharto, Iman, 1999, Manajemen Proyek: Dari Konseptual Operasional, Edisi 2, Cetakan 1, Jakarta, Erlangga.

[4].Cluogh, Richard H., and Searcs, Glenn A., 1991, Construction Project Management, Canada, Jonh Willey \& Sons Inc.

[5].Rini, J.F, 2006, Artkel : Beberapa Kiat Wanita Bekerja, e-psikologi.com 